\title{
STUDI NARASI MENGENAI PENTAHBISAN TEMBOK YERUSALEM MENURUT NEHEMIA 12:27-43
}

\author{
Farel Y. Sualang \\ Sekolah Tinggi Teologi Injili Indonesia Yogyakarta \\ E-mail: Sualangfarel@gmail.com
}

\begin{abstract}
The Meaning of the Ordination of the Jerusalem Wall in Nehemiah 12:27-43 discusses two processes, each of which was led by a group of choirs, traveling from the opposite direction along the upper part of the vast wall. The Israelites met in the Temple area and ended with thanksgiving and sacrifices. This scientific work uses a text research methodology with a specific narrative genre in the form of story reports. The report on the dedication of the walls of Jerusalem does not reveal a problem or a resolution. The text only describes the sequence of events (facts) in the dedication of the walls of Jerusalem. The dedication ceremony for the Jerusalem wall was a report from Nehemiah. The text of Nehemiah 12: 27-43 only describes events that occurred during the celebration of the dedication of the walls of Jerusalem. The theological significance in the Ordination of the Jerusalem Wall according to Nehemiah 12: 27-43 shows the role of God (God gives joy, God guides the repair of Jerusalem's walls), the importance of giving thanks, and the importance of God's people in praising God.
\end{abstract}

Keywords: Nehemiah, Ordination,Narration.

\begin{abstract}
Abstrak
Makna Pentahbisan Tembok Yerusalem dalam Nehemia 12:27-43 membahas mengenai dua proses, yang mana masing-masing dipimpin oleh serombongan paduan suara, berjalan dari arah yang berlawanan sepanjang bagian atas tembok yang luas itu. Orang-orang Israel bertemu di daerah Bait Suci dan diakhiri dengan ucapan syukur dan persembahan kurban. Karya ilmiah ini menggunakan metodologi penelitian teks dengan genre narasi secara khusus dalam bentuk laporan cerita. Laporan mengenai Pentahbisan tembok Yerusalem tidak menyatakan suatu problema ataupun resolusi. Teks tersebut hanya menjelaskan runtutan kejadian (fakta) dalam pentahbisan tembok Yerusalem. Upacara pentahbisan tembok Yerusalem merupakan laporan dari Nehemia. Teks Nehemia 12:27-43 hanya menjelaskan peristiwa-pristiwa yang terjadi dalam perayaan pentahbisan tembok Yerusalem. Makna Teologis dalam Pentahbisan Tembok Yerusalem menurut Nehemia 12:27-43 menunjukan Peran Allah (Allah memberi sukacita, Allah menuntun perbaikan tembok Yerusalem), Kepentingan terhadap pemberian korban syukur, serta Kepentingan umat Allah dalam memuji Tuhan.
\end{abstract}

Kata Kunci: Nehemia, Pentahbisan, Narasi. 


\section{PENDAHULUAN}

Pentahbisan tembok Yerusalem di dalam Nehemia 12:27-43, merupakan suatu tindakan ucapan terima kasih bangsa Israel kepada Allah. Hal ini dilatar belakangi oleh keinginan Nehemia untuk memulihkan kondisi negeri nenek moyangnya yaitu tanah Yerusalem dengan meminta izin kepada raja Artahasta pada jaman itu (Neh. 2:1-10). Observasi tembok Yerusalem yang telah dirobohkan menjadi dasar bagi Nehemia agar dapat memanggil orangorang Yahudi (Neh. 2:19-20). Selanjutnya, Nehemia melanjutkan kepada pembagian kerja untuk membangun kembali tembok Yerusalem (Neh. 3:1-32). Hal ini terlihat dalam pangabdian orang Israel terhadap pembangunan tembok (Neh. 3:1-6:19).

Nehemia sebagai pemimpin dalam pembangunan tembok Yerusalem memiliki tantangan dalam pembangunan ini. Hal tersebut dapat diperhatikan ketika orangorang non-Yahudi mencoba untuk mengganggunya. Sanbalat dan kawankawannya mengusahakan untuk menghalangi pembangunan tembok Yerusalem (Neh. 2:10; 4:7-9). Sikap yang

\footnotetext{
${ }^{1}$ Francis Brown, The New Hebrew and English Lexicon With An Appendix Containing The Biblical Aramic (United states of America: Hendrickson Publisher, 1979). 392.
}

diambil oleh Nehemia mengakibatkan kepada suatu pembaruan-pembaruan bagi bangsa Israel (Neh. 7-10).

Pembaruan tersebut dapat dilihat dari sisi kependudukan dan religius. Mengenai hal kependudukan dapat diperhatikan bahwa sikap Nehemia dapat ditujukan pada sensus orang-orang yang kembali dari pada pembuangan (Neh. 7:5-73). Dari sisi religius, Ezra sebagai ahli taurat membacakan hukum taurat dan seluruh orang Israel merayakan pondok Daun (Neh. 8:1-18). Pembaharuan masih berkelanjutan sampai kepada pengakuan dosa dan permintaan doa yang dipimpin oleh orangorang Lewi (Neh. 9:4-5), serta perjanjian untuk menaati hukum Allah (Neh. 9:110:39).

Penulis memfokuskan pada 3 hal pokok mengenai perayaan pentahbisan tembok Yerusalem dalam Nehemia 12:2743. Pertama, "hx'm.f "simekhah" diartikan sukacita dan kesenangan (Neh. 12:27). ${ }^{1}$ Kedua, שִׁיר "syir" diartikan sebagai nyanyian lagu dan puji-pujian (Neh. 12:27b). ${ }^{2}$ Ketiga, זבְ “zebakh” diartikan sebagai korban syukur, korban keselamatan

\footnotetext{
${ }^{2}$ Carl A. Reed, Diktat Kuliah, Kamus Sementara Bahasa Ibrani-Bahasa Indonesia Edisi kedua, sem. VI, 2010.
} 
(Neh. 12:43). ${ }^{3}$ Penulis akan mencari makna ketiga pokok tersebut dari perayaan pentahbisan tembok Yerusalem.

Menurut penulis, ada 3 (tiga) hal yang menjadi keperluan utama dalam pembahasan upacara pentahbisan tembok Yerusalem (Neh. 12: 27-43). Pertama, kondisi bangsa Israel pada pasca pembuangan di Babel. Kehidupan bangsa Israel yang cenderung untuk melakukan dosa (Neh. 9:28-35). Kemuliaan Allah seakan-akan hilang ketika Bait Allah yang baru sangat berbeda dengan Bait Allah sebelumnya (Neh. 3:12-13). Kasus perkawinan campuran terjadi pada masa Pembuangan dan dosa-dosa yang meliputi orang-orang Israel yang cenderung pada sifat keras tengkuknya. ${ }^{4}$ Sehingga, akibat dosa menjadi harapan yang tidak baik bagi bangsa Israel. Hal ini dijadikan sebagai suatu dasar dalam tantangan Nehemia dari sisi kehidupan rohani Israel.

Tantangan Nehemia dapat dilihat dari pembanguan proyek tembok Yerusalem (Neh 4 -6). Peran Sanbalat dan kawankawannya (Tobia dan Gesyem) sangat aktif untuk mencegah pembangunan tembok Yerusalem. Secara tidak langsung hal ini

\footnotetext{
${ }^{3}$ Ibid.

${ }^{4}$ David M. Howard, Kitab-kitab sejarah (Malang: Gandum Mas, 2009). 375.
}

juga mempengaruhi bangsa Israel terhadap keluhan-keluhan kepada Nehemia.

Dampak dari permasalahan dan kasus-kasus yang ditemukan dapat diperhatikan terhadap sifat jati diri umat Allah. Arti penting terhadap makna Pentahbisan tembok Yerusalem yang dianggap sudah tercemar dan tidak memiliki arti sama sekali. Hal ini disebabkan oleh perbuatan dosa umat Israel sebagai suatu kecacatan total sampai pada akhir dari kitab Nehemia (Neh. 13). ${ }^{5}$

Kedua, penulis memperhatikan sumbersumber literatur yang terbatas untuk menjelaskan nats ini. Hal tersebut dibuktikan dengan terbatasnya penerjemahan buku-buku tentang Nehemia dalam bahasa Indonesia. Penerbit bukubuku rohani di Indonesia sangat kurang dalam pembahasan tentang kitab Nehemia. Ketiga, penulis membahas pentahbisan tembok Yerusalem agar dapat menemukan makna teologis dari hasil eksegesis Nehemia 12:27-43. Hal ini dijadikan sebagai nilai praktis atau sumbangsih dalam konteks Kekristenan saat ini yang didasarkan kepada Alkitab, sehingga dapat menemukan makna pentahbisan tembok

\footnotetext{
${ }^{5}$ Ibid. Ched Spellman, “Nehemiah's New Shadow: Reading and Rereading the Ezra-Nehemiah Narrative," Southeastern Theological Review 9, no. 1 (2018): 3 , https://digitalcommons.cedarville.edu/biblical_and_ ministry_studies_publications/437/.
} 
Yerusalem bagi masa kini.

\section{METODOLOGI PENELITIAN}

Karya ilmiah ini akan memakai metodologi penelitian dengan pendekatan Hermeneutika genre Narasi dengan sub berupa Laporan. ${ }^{6}$ Untuk mendalami makna pentahbisan tembok Yerusalem (Neh. 12:27-43), maka ada 4 (empat) Analisis yang dipakai dalam karya ilmiah ini.

Pertama, Analisa literal. Penafsiran literal sangat penting untuk mencari arti normal dalam pengggalian teks. Menurut Saparman, Yang dimaksud dengan prinsip penafsiran literal adalah bahwa biasanya penulis menuliskan sebuah kata/frasa memakai kata-kata dengan arti yang biasa (normal). Arti yang dipakai dalam bahasa sehari-hari waktu itu. Prinsip ini mengartikan sebuah kata/frasa sesuai dengan arti pada umumnya yang dipakai masyarakat. $^{7}$

Analisa Literal merupakan salah satu cara yang terbaik dalam menafsirkan

\footnotetext{
${ }^{6}$ Narasi yang paling sederhana dalam Alkitab, blok yang paling mendasar dari bangunan Narasi Alkitab, adalah Laporan: sebuah "narasi yang singkat, berdiri sendiri, sering kali dalam gaya orang ketiga, tentang suatu peristiwa atau situasi tunggal yang terjadi pada masa lampau. Biasanya sub-genre ini menceritakan fakta-fakta dari peristiwa yang telah terjadi dengan menggunakan gaya langsung tanpa diembel-embel kesusastraan. Willian W. Klein, Craig Blomberg, dan Robert L. Hubbard, Introduction to Biblical Interpretation 2 (Malang: Literatur SAAT, 2013), 204-209. Selain Genre Narasi, adapun Genre Hukum, Puisi, Nubuatan dan penggunaan Genre Hikmat dalam Perjanjian Lama. Farel Yosua
}

laporan narasi teks Nehemia 12:27-43 mengenai pentahbisan tembok Yerusalem. Pokok-pokok dari perayaan pentahbisan tembok Yerusalem diharuskan memakai metode penafsiran literal. Hal tersebut digunakan untuk mencari arti normal (sesungguhnya) di dalam kata dan frasa.

Kedua, penafsiran gramatikal. "Penafsiran gramatikal adalah menafsirkan Alkitab menurut tata bahasa." 8 Saparman berpendapat bahwa penulis kitab menulis menggunakan kata-kata yang disusun sehingga satu kata dengan kata yang lainnya berhubungan. $^{9}$ Metode penafsiran ini difokuskan pada penyelidikan terhadap struktur kitab, pasal dan ayat yang digunakan oleh penafsir kitab. Penulis akan memperhatikan penafsiran ini untuk dapat mengetahui makna dari pentahbisan tembok Yerusalem.

Ketiga, metode penafsiran kontekstual. Penafsiran kontekstual digunakan untuk mencari makna teks dengan mempelajari bagian-bagian sebelum dan sesudah nats. ${ }^{10}$

Sualang, "Prinsip-Prinsip Hermeneutika Genre Hikmat Dalam Kitab Amsal: Suatu Pedoman Eksegesis," Jurnal PISTIS 1, no. Old Testament, Genre of Wisdom, Hermeneutics (2019): 93-112, https://doi.org/10.31227/osf.io/xmk6h.

\footnotetext{
${ }^{7}$ Saparman, Belajar Alkitab (Yogyakarta: STII Press, 2007), 89.

${ }^{8}$ Ibid.

${ }^{9}$ Ibid

${ }^{10}$ Ibid, 102.
} 
Jurnal Teologi \& Pelayanan ( Kerusso )

E-ISSN: 2714-9587

P-ISSN: 2407-554X

Penafsiran kontekstual sangant penting digunakan mengingat arti untuk kata-kata bergantung pada kalimatnya dan arti untuk kalimat-kalimat bergantung pada paragrafnya. Penafsiran kontekstual sangat baik dalam pembahasan laporan Narasi teks Nehemia 12:27-43. Konteks sebelum dan sesudah nats akan diperhatikan oleh penulis dalam mencari makna teologis pentahbisan tembok Yerusalem.

Keempat, penafsiran teologis. Penafsiran teologis adalah prinsip penafsiran yang menyatakan bahwa Alkitab secara menyeluruh adalah konteks yang paling luas. Hal tersebut dapat diperhatikan ketika para penafsir menata perikop-perikop ke dalam telogi Alkitab. Penafsiran teologis akan menunjukkan makna asli kepada penafsir dan membangun suatu jembatan kepada doktrin bagi masa kini. ${ }^{11}$ Pembahasan mengenai pentahbisan tembok Yerusalem akan memakai metode penafsiran teologis. Metode tersebut akan dipakai dalam laporan narasi untuk menemukan prinsip-prinsip teologis.

Penulis akan menggunakan Alkitab, buku-buku, kamus-kamus yang sesuai dengan judul atau topik yang terkait dengan teks dalam proses penafsiran. Serta, Penulis

\footnotetext{
${ }^{11}$ Grant R. Osborne, Spiral Hermeneutika: Pengantar Komprehensif bagi Penafsiran Alkitab (Surabaya: Penerbit Momentum, 2012), 494.

${ }^{12}$ Richard L. Pratt, Jr, Ia Berikan KisahNya:

Panduan bagi Siswa Alkitab untuk Menafsirkan
}

akan menambahkan penguraian atau penggalian teks secara sistematis. Dalam bagian ini penulis tidak hanya dibantu oleh sumber-sumber buku, melainkan juga sumbangsi dan koreksi dari dosen pembimbing.

\section{PEMBAHASAN}

\section{Struktur Sastra Nehemia 12:27-43}

Teks Nehemia 12:27-43 merupakan teks yang berupa laporan (report). ${ }^{12}$ Laporan tentang pentahbisan tembok Yerusalem tidak menyatakan suatu problema ataupun resolusi. Teks tersebut hanya menjelaskan runtutan kejadian (fakta) dalam pentahbisan tembok Yerusalem. Menurut Richard L. Pratt, Jr, Laporan terutama menggambarkan situasinya. Penyusunannya yang bersifat sementara lebih dari hanya sekedar suatu daftar fakta, namun tidak lebih dari itu. Kadang-kadang mereka memberi sumabngsih kepada struktur konteks yang lebih luas, tapi pada dirinya sendiri episodeepisode ini Cuma menggambarkan sedikit ketegangan dramatis. ${ }^{13}$ Upacara pentahbisan tembok Yerusalem merupakan laporan dari Nehemia. Teks Nehemia 12:27-43 hanya

Narasi Perjanjian Lama (Surabaya: Penerbit Momentum, 2005).204.

13 Ibid. 
Jurnal Teologi \& Pelayanan ( Kerusso )

E-ISSN: 2714-9587

P-ISSN: 2407-554X

menjelaskan peristiwa-pristiwa yang terjadi dalam perayaan pentahbisan tembok Yerusalem. Namun, teks ini tidak menjelaskan adanya problema dan resolusi. ${ }^{14}$

\section{Struktur kitab Nehemia}

Kitab Nehemia adalah buku dari seorang tokoh pembangunan. ${ }^{15}$ Kitab Nehemia dimulai pada saat kondisi bangsa Israel mulai membentuk kepada pembangunan fisik maupun rohani. Penulisan kitab Nehemia dibuat seperti sebuah cerita yang kompleks. Menurut John C. Whitcomb, Jr, keseluruhan kitab Nehemia terdiri dari 6 bagian yang terdiri dari, Bagian pertama adalah Nehemia tiba di Yerusalem (1:1-2:20) yang terdiri dari berita menyedihkan dari Yerusalem dan doa Nehemia (1:1-11), permohonan Nehemia dikabulkan (2:1-8) dan survei Nehemia atas tembok-tembok dan laporannya (2:9-20). Bagian kedua adalah pembangunan Tembok (3:1-6:19) yang terdiri dari para pekerja dan tugas-tugas mereka (3:1-32), perlawanan dari musuh (4:1-23), aneka pembaharuan yang dilakukan Nehemia selaku Gubernur (5:1-19) dan pembangunan

\footnotetext{
${ }^{14}$ Ibid.

${ }^{15}$ Richard H. Seume, Nehemiah: God's Builders (Chicago: Moody Press, 1978), 11.
}

tembok selesai sekalipun ada sejumlah Intrik (6:1-7:4). Bagian ketiga adalah aneka pembaharuan sipil dan religious di Yerusalem (7:5-10:39) yang terdiri dari daftar orang Yahudi yang kembali bersama Zerubabel (7:5-73), pembacaan hukum Allah dan ketaatan pada hukum Allah (8:118) dan sebuah pengakuan umum dan perjanjian (9-10:39). Bagian keempat adalah daftar penduduk (11:1-12:26). Bagian kelima adalah penahbisan tembok dan pengaturan pelayanan bait Allah (12:27-47). Bagian keenam adalah aneka pembaruan terakhir Nehemia (13:1-30). ${ }^{16}$

Kitab Nehemia menunjukkan 2 (dua) tempat yang dicatat di dalam perjalanannya, yaitu Puri Susan dan Yerusalem. Pertama, Puri Susan (Neh. 1:1), merupakan Ibu kota kerajaan Persia yang menjelaskan situasi pada awal tekad Nehemia untuk membangun tembok Yerusalem. Di dalam pasal 1 sampai pada pasal 2:1-10, menjelaskan hal serupa terlebih pada percakapan antara Nehemia dan Raja Artahsasta.

Kedua, Yerusalem (Neh. 2:11-13:31). Kota Yerusalem merupakan tujuan utama dalam kitab Nehemia. Sejak keberangkatan Nehemia ke Yerusalem (Neh. 2:11) dan

\footnotetext{
${ }^{16}$ Charles F. Pfeifer dan Everett F. Harrison, peny., John C. Whitcomb, jr, The Wycliffe Bible Commentary (Malang: penerbit Gandum Mas, 2004), 1163-1164.
} 
catatan terhadap pulangnya bangsa Israel dari tanah Persia (Neh. 7:4-73), Hampir keseluruhan kitab menjelaskan situasisituasi yang terjadi di kota tersebut. Pembangunan kembali baik Infastruktur kota, sipil dan Rohani merupakan ketiga bagian yang terjadi pada di Yerusalem. ${ }^{17}$

Ada tiga karakter yang memegang paranan utama dalam peristiwa pada kitab Nehemia, yaitu: Nehemia, termasuk sosok tokoh yang berhasil dalam pemulihan kembali Yerusalem. Nehemia adalah 'anak Hakhalya' (1:1) dan dari suku Yehuda (2:3). Sempat menanggungjawab sebagai juru minuman raja (Neh. 1:1-2:10). Termasuk sebagai jabatan yang tinggi dalam era kerajaan Persia sebagai salah satu kepercayaan raja dalam urusan rumah tangga.

Nehemia memiliki tekad dalam melaksanakan tugas besar untuk membangun tembok Yerusalem (2:2-11). Tekad tersebut diperjelas kepada percakapan dengan raja Artahsasta untuk dapat kembali ke Yerusalem. Dalam keinginan yang kuat dalam pembaharuan Yerusalem, Nehemia membangun dinding tembok Yerusalem (2:11:9-19).Sosok

\footnotetext{
${ }^{17}$ Israel Finkelstein, "Jerusalem in the Persian (and Early Hellenistic) Period and the Wall of Nehemiah," Journal for the Study of the Old Testament 32, no. 4 (2008): 501-20, https://doi.org/10.1177/0309089208093928.
}

pemimpin juga didapatkan ketika Nehemia memberikan pemabagian tugas dan pekerjaan yang tertib. Nehemia mengatur para pekerja (3:10-30), sehingga tujuan pembanguan dapat terlaksana.

Selain itu ia merupakan pemimpin sebagai gubernur Yerusalem di bawah pemerintahan Persia (8:10). Masalah infrastruktur, kependudukan dan rohani dapat diselesaikan oleh Nehemia. Oleh sebab itu, dalam kitab kecil ini terlihat 3 kecakapan dalam diri Nehemia: 1) sebagai juru minuman raja; 2) pembangunan dinding kota Yerusalem dan 3) kepala daerah. ${ }^{18}$

Kedua, Raja Arthasasta memerintah dari tahun 465-425 SM. ${ }^{19}$ Dalam kitab Nehemia, Raja Arthasasta dicatat beberapa kali dalam bagian kitab tersebut (Neh. 12:1-10;5). Raja Arthasasta merupakan seorang tokoh dibalik perizinan kembalinya Nehemia dan pembangunan tembok di Yerusalem (2:1-10).

Pada masa pemerintahannya, Raja Arthasasta banyak memberikan kepercayaan kepada Nehemia. Salah satunya adalah Raja Artahsasta mengangkat Nehemia sebagai bupati di tanah Yudea

\footnotetext{
${ }^{18}$ J. Sidlow Baxter,menggali isi Alkitab 1 Kejadianester (Jakarta: Yayasan Komunikasi Bina Kasih, 2009), 459.

${ }^{19}$ The Interpreter's Dictionary of the Bible (New York: Abingdon Press, 1962), 742.
} 
(Neh. 5:14). Sosok Raja Arthasasta dapat dikatakan sebagai tokoh yang banyak mendukung orang-orang Yahudi pada masa pasca pembuangan, seperti memulangkan banyak orang-orang Yahudi kembali ke Yerusalem (Neh. 7:4-73).

Tokoh yang terakhir dalam dunia peran/perfilman disebut antagonis ${ }^{20}$ yang dimainkan oleh Sanbalat dan Tobia. Dalam kitab Nehemia, Sanbalat dan Tobia cukup dijelaskan dalam kitab tersebut (Neh. 4-6). Sanbalat dan Tobia adalah sosok yang sangat menentang Nehemia untuk membangun Tembok Yerusalem. Kedua tokoh tersebut mencoba untuk memprovokasi orang-orang Samaria (Neh. 4:1-3). Serta, mencoba untuk membunuh Nehemia melalui pertemuan di Kefirim, di lembah Ono (Neh. 6). Namun, Kedua tokoh tersebut tidak mampu dalam menghalangi Nehemia membangun tembok Yerusalem. Tepat dalam teks Nehemia 6:15-16, pembangunan Tembok Yerusalem selesai.

$$
\text { Penyusunan struktur yang }
$$

digambarkan menuangkan karya-karya sastra yang mengherankan dalam kitab Nehemia. Inilah sumber dari kembalinya kehidupan nasional, hukum dan agama bagi Israel. Keseluruhan peristiwa, tokoh yang

\footnotetext{
${ }^{20}$ Antagonis adalah orang yang melawan, tokoh karya sastra yang merupakan penentang tokoh utama. Departemen Pendidikan Nasional, Kamus Besar Bahasa Indonesia Pusat Bahasa Edisi
}

terlibat, lokasi, kembalinya aturan-aturan, menambah kekayaan struktural dari ayat per ayat, pasal per pasal, sehingga penggabungan semua peristiwa dalam Kitab Nehemia diuraikan dengan baik.

Konteks Teks Berdasarkan Kitab NehemiaKitab Nehemia berisikan 13 pasal. Pasal-pasal dalam kitab Nehemia menunjukkan suatu penggolongan sesuai dari tahap-tahap pembaruan oleh Ezra dan Nehemia yang tercantum dalam uraian ayatayatnya. Menurut Merril F. Unger dapat dibagi 2 bagian besar yaitu: Pertama, restorasi Nehemia terhadap tembok Yerusalem pasal 1-7 yang dibagi dalam beberapa kategori sebagai berikut: pemanggilan Nehemia (1-2:20), para pembangun pintu gerbang domba (3:1-32), perlawanan dalam pekerjaan (4-5:19), pembangunan tembok selesai (6:1-19) dan daftar orang-orang kembali bersama Zerubabel (7:1-73). Kedua, reformasi Ezra dan Nehemia pasal 8-13 yang juga dibagi dalam point-point sebagai berikut: pembacaan hukum Allah (8:1-12), kembalinya kebangkitan rohani (9:1-38), pembacaan perjanjian (10:1-39), penahbisan tembok Yerusalem (11-12:2747) dan memperbaiki kejahatan (13:1-29). ${ }^{21}$

keempat (Jakarta: PT Gramedia Pustaka Utama, 2012), 73.

${ }^{21}$ Merril F. Unger, Unger's Bible Handbook (Chicago: Moody Press, 1967), 260-263. 
Penulisan teks dalam penahbisan tembok Yerusalem tercatat pada pasal 1112:27-47, khusus bahasan dalam prosesi penahbisan tembok Yerusalem dapat diperhatikan pada ayat 27-43. Hampir keseluruhan penafsir kitab dari beberapa sumber literature menyetujui penempatan bagian tersebut, seperti Hill dan Walton menyimpulkan ini sebagaian dari penahbisan tembok Yerusalem (12:27$13: 3) .^{22}$

Karena pasal 12:27-43 menjadi peristiwa yang diangkat oleh penulis maka tentunya penulis melihat teks ini juga sebagai suatu bagian khusus yang ditempatkan dalam struktur kitab. Secara khusus, penulis menyimpulkan bahwa pasal 12:27-43 dapat dikategorikan sebagai puncak dari penulisan kitab Nehemia. Penulis melihat bagian ini masuk kepada hasil dari perjuangan Nehemia dalam pembangunan tembok Yerusalem (ps.3-6). Oleh karena itu, hal ini menghasilkan suatu pengucapan syukur dalam penahbisan tembok kepada Allah.Konteks Teks sebelum dan sesudah Nehemia 12:27-43

Konteks sebelum pasal ini difokuskan kepada pemanggilan Nehemia untuk membangun tembok Yerusalem, dapat dilihat pasal 1-2. Mendengar informasi dari
Hanani bahwa tembok Yerusalem telah rusak dan terbongkar, Nehemia berseru kepada Allah untuk dapat pergi ke Yerusalem. Atas persetujuan Arthasasta kembali Nehemia ke Yerusalem.

Pembangunan dilakukan bersama-sama dengan beberapa orang Israel (ps. 3-6). Nehemia sebagai tokoh dalam pembaharuan di Israel memiliki tantangan yang cukup berat. Sanbalat dan Tobia menjadi orang yang menentang pembangunan tembok Yerusalem, sehingga Nehemia mengeluarkan pembaharuan terhadap keluhan-keluhan orang Israel. Keputusankeputusan tersebut mempercepat pembangunan tembok Israel, walaupun masih ada usaha Sanbalat dan Nehemia membunuh Nehemia (ps. 6).

Pembaharuan terhadap sipil dan religious diatur dalam pasal 7-12:1-26. Kembalinya orang-orang Israel dari pembuangan membuat Nehemia untuk melakukan sensus penduduk. Dengan kembalinya orang-orang Israel dari pembuangan, pangaturan tata kehidupan rohani Yahudi diatur kembali.

Peran dari imam Ezra mengembalikan pengaruh kerohanian orang-orang Yahudi yang dipulihkan kembali dengan upacaraupacara keagamaan (ps. 8-10). Sehingga,

${ }^{22}$ Andrew, E. Hill dan John, H. Walton, Survey Perjanjian Lama (Malang: Gandum Mas, 2008),374. 
Jurnal Teologi \& Pelayanan ( Kerusso )

E-ISSN: 2714-9587

P-ISSN: 2407-554X

tatanan kehidupan keagaamaan

mempengaruhi kepada kembalinya para iman dan orang-orang Lewi yang hendak melayani bait Allah.Konteks sesudahnya dari pasal 12:44-13:31, setelah penahbisan tembok Yerusalem. Dijelaskan kembali peran-peran orang Lewi, khususnya kembalinya jaminan hidup terhadap pengaturan persembahan perbendaharaan, sebagai pelaksana tugas pelayanan Allah (ps. 12:44-47). Serta diaturnya kembali orang-orang Israel dalam menegaskan semua pencemaran dan pemisahan dari orang-orang yang bukan Israel, serta kembali memulihkan peribadatan yang benar.

\section{Konteks pasal 12:27-43}

Kitab Nehemia pasal 12:27-43 bila diamati dengan teliti dapat dibagi menjadi tiga (3) bagian besar. Pertama, Orang-orang Lewi dipanggil segala tempat (ay. 27-30). Orang-orang Lewi dibagi dalam beberapa kelompok dari beberapa desa dan dikumpulkan di kota Yerusalem. Kelompok tersebut ditugaskan sebagai penyanyi dengan memberikan pengucapan syukur dan pentahiran diri kepada Allah.

Kedua, Nehemia memberikan kesempatan kepada paduan suara pertama (ay. 31-37). Nehemia mengisahkan dua paduan suara yang diarahkan pada tembok
Yerusalem. Secara khusus, diarahkan dari pintu gerbang sampah (ay.31). pada rombongan paduan suara pertama ini dipimpin oleh Ezra untuk mengelilingi tembok, istana Daud dan pintu gerbang air.

Ketiga, Nehemia memberikan kesempatan kepada paduan suara kedua (ay. 38-43). Paduan suara kedua diikutsertakan Nehemia (sebagai pemimpin) dan para imam. Paduan suara kedua bertugas untuk mengelilingi tembok Yerusalem dari arah utara ke timur sampai menuju pada bait Allah (ay. 38-42). Sampai di dalam bait Allah, kelompok tersebut mempersembahkan korban-korban (ay. 43). Konteks pasal 12:27-43, menunjukkan suatu peristiwa dalam prosesi Pentahbisan tembok Yerusalem. Nehemia dan Ezra turut serta dalam prosesi tersebut, disamping peranan para imam dan orang-orang Lewi dalam upacara tersebut. tentunya dalam bagian nats ini ada beberapa upacara yang dilakukan oleh bangsa Israel.

\section{Persiapan Pentahbisan Tembok Yerusalem (12:27-30)}

Naratif Nehemia 12:27-43 merupakan suatu lanjutan sejarah dari Nehemia 11:2-26 mengenai daftar orang-orang Lewi pada 
Jurnal Teologi \& Pelayanan ( Kerusso )

E-ISSN: 2714-9587

P-ISSN: 2407-554X

waktu zaman Zerubabel. ${ }^{23}$ Oleh sebab itu,

Nehemia 11:2-26 akan memberikan

keterangan mengenai daftar orang-orang

Lewi yang bekerja kembali di dalam

pentahbisan tembok Yerusalem (Neh.

12:27). Penulis akan menjelaskan beberapa persiapan awal di dalam perayaan pentahbisan tembok Yerusalem. Orang Lewi dikumpulkan di Yerusalem (12:27)

Pada awal narasi, pentahbisan tembok Yerusalem melibatkan orang Lewi yang telah dikumpulkan dari seluruh tempat di sekitar Yerusalem (Band. Neh. 12:28). Orang Lewi diberikan tugas untuk mengadakan perayaan dalam pentahbisan ini. Apabila memperhatikan bagian dari teks Ibrani Nehemia 12:27,

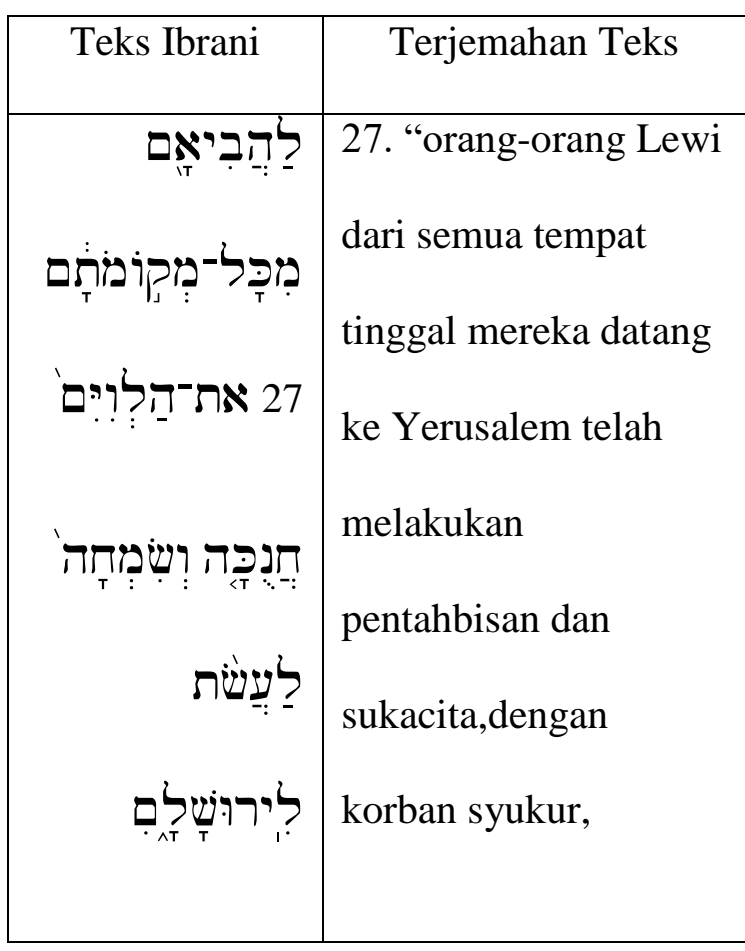

${ }^{23}$ J. Carl Laney, Ezra-Nehemia (Chichago: Moody Press, 1982), 114.

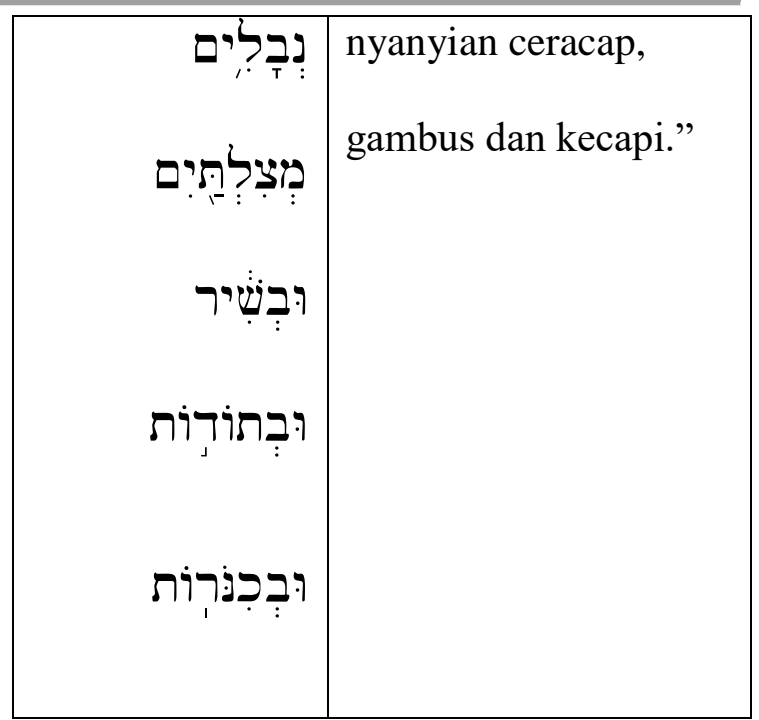

Hasil terjemahan bahasa Indonesia di atas, pentahbisan Tembok Yerusalem dilakukan dalam keadaan sukacita. Kata Ibrani yang

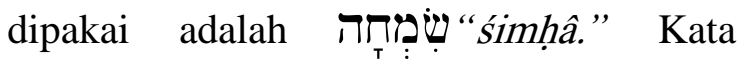
tersebut dapat diartikan sebagai bersukacita, menyenangkan, membuat (orang) bersukacita. $^{24}$ Dalam Nehemia 12:27-43, kata bersukacita dipakai 2 (dua) kali pada teks ini. Pada nats selanjutnya, kata bersukacita dipakai hanya 1 (satu) kali dalam Nehemia 12:44 yang menjelaskan Yehuda bersyukur atas para imam dan orang Lewi yang kembali bertugas sesuai pekerjaanya.

Dalam persiapan pentahbisan

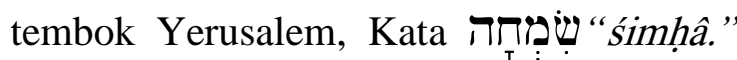

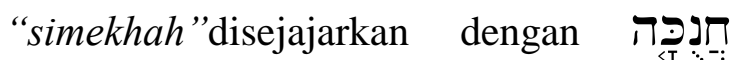
"ḥănūkkâ" dengan memakai kata sambung ? " $\mathrm{w}$ "” yang diterjemahkan "dan." Frase ini dapat diartikan bahwa orang Lewi mengadakan pentahbisan dan sukacita. Pentahbisan tembok Yerusalem tidak akan lepas dari keadaan bangsa Israel yang bersukacita di sepanjang acara pentahbisan ini. Hal tersebut nampak kembali pada ayat 43 dan 44. Oleh sebab itu, kata bersukacita merupakan pokok yang utama dalam pentahbisan tembok Yerusalem (Neh. 12:27-43). Keadaan sukacita ini

${ }^{24}$ Carl A. Reed, Diktat Kuliah, Kamus Sementara Bahasa Ibrani-Bahasa Indonesia Edisi kedua, sem. VI, 2010. 
diungkapkan dengan 2 (hal) pada ayat 27. Pertama mengenai korban syukur dan kedua mengenai puji-pujian.

$$
\text { Pertama, pentahbisan tembok }
$$

Yerusalem dilakukan dengan korban syukur. Kata Ibrani yang dipakai adalah "tôdôt." Diartikan dalam bahasa Indonesia sebagai korban syukur, korban syukur dengan puji-pujian. "tôdôt" adalah istilah teknis untuk persembahan pujian dalam sistem korban Lewi. ${ }^{26}$ Dalam konteks dekat, Imamat 7:15 menjelaskan korban persembahan "tôdâ" yang dijadikan sebagai korban keselamatan. ${ }^{27}$ Menurut hukum taurat, jika seseorang menerima kebaikan dari Allah, baik dalam pujian kepada Allah karena berbagai alasan, pengakuan publik harus disertai dengan pengorbanan, yaitu korban keselamatan untuk tôdâ (Imamat 7). ${ }^{28}$ Menurut Carl Reed, Biasanya korban keselamatan akan menjadi makan komunal (jika itu adalah hewan), hanya sebagian kecilnya dibakar di atas mezbah. Si penyembah, para imam yang melayaninya, teman-teman penyembah, dan orang-orang laindari Jemaah (terutama yang miskin) akan ikut dalam pesta ini. Mereka mendengarkan pengakuan publik si penyembah sementara hewan itu dibakar di atas mezbah: dengan demikian, mereka akan menyadari bahwa merekapun ikut dalam karunia yang Allah telah memberi kepada si penyembah itu. ${ }^{29}$

Dalam konteks dekat, 2 Tawarikh 29:31-33 dijelaskan mengenai pelaksanaan korban syukur yang diikutsertakan dengan puji-pujian dan kerelaan hati dalam

\footnotetext{
25 Brown, The New Hebrew and English Lexicon, 392.

${ }^{26}$ Carl A. Reed, Diktat Kuliah, Eksposisi kitab Mazmur, Program S-2, April 2014.

${ }^{27}$ Hannah Harrington, "The Use of Leviticus in Ezra-Nehemiah," Journal of Hebrew Scriptures 13 (2013): 1-19, https://doi.org/10.5508/jhs.2013.v13.a3. 28 Ibid.
}

membawakan korban bakaran (ay. 31). Isi dari korban bakaran adalah lembu, domba jantan dan domba muda yang diberikan kepada para imam dan orang Lewi untuk diserahkan kepada Tuhan (ay. 32-33). Pelaksanaan korban bakaran yang dilakukan oleh Raja Hizkia menjelaskan bagaimana ia menguduskan kembali rumah Tuhan.

Korban syukur di dalam pentahbisan tembok Yerusalem (Neh. 12:27-43) diikutsertakan dengan mengorbankan binatang sebagai rasa ucapan terima kasih kepada Allah karena tembok Yerusalem telah dibangun. Korban syukur merupakan pengakuan publik bagi seluruh umat Israel yang dilayani oleh orang Lewi. Kedua, pentahbisan tembok Yerusalem dilakukan dengan pujian. Kata Ibrani yang dipakai adalah שִׁיר "shîr." Diartikan dalam bahasa Indonesia sebagai nyanyian, lagu dan puji-pujian. ${ }^{30}$ Pentahbisan tembok Yerusalem puji-pujian ini diiringi dengan ceracap, gambus dan kecapi. Sukacita dalam pentahbisan tembokYerusalem tidak lepas dari pujipujian yang dilakukan orang Lewi. Bahkan, puji-pujian di dalam pentahbisan tembok Yerusalem mengambil peran penting pada keseluruhan acara (Neh. 12:28-29). ${ }^{31}$

\footnotetext{
${ }^{29}$ Reed, Diktat Kuliah, Eksposisi kitab Mazmur, Program S-2, April 2014.

${ }^{30}$ Bible Works: "שִיריר" dalam Bible Works NT $(B N T)$, ver. 7.0, Software:Bible Works For Windows. CD-ROM.

${ }^{31}$ Pfeifer dan Everett F. Harrison, peny., John C. Whitcomb, jr, The Wycliffe Bible Commentary Volume 1, 1187.
} 
Jurnal Teologi \& Pelayanan ( Kerusso )

E-ISSN: 2714-9587

P-ISSN: 2407-554X

Pendirian kota di sekitar Yerusalem 12:28

29Nehemia 12:28-29 menjelaskan

bagaimana para penyanyi membangun

kota-kotanya di sekitar Yerusalem. Di

dalam bagian teks Ibrani Nehemia 12:28,

\begin{tabular}{|c|c|}
\hline Teks Ibrani & Terjemahan Teks \\
\hline 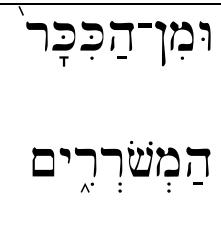 & $\begin{array}{l}\text { 28. lalu berkumpulah para } \\
\text { penyanyi-penyanyi dari } \\
\text { daerah sekitar Yerusalem, } \\
\text { dari desa-desa orang } \\
\text { Netofa }\end{array}$ \\
\hline בִּנִיני & \\
\hline 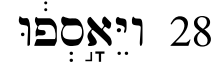 & \\
\hline נְטּבָתָיִ: & \\
\hline 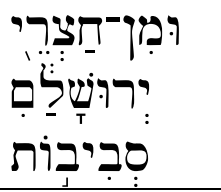 & \\
\hline
\end{tabular}

Tercatat dalam Nehemia 12:28-29 bahwa para para penyanyi berasal dari desa-desa orang Nestofa, Bet-Gilgal, padang Geba dan Asmawet yang berasal dari sekitar Yerusalem.

Desa Nestofa dicatat dalam bagian tempat daftar penduduk Yerusalem yang dikategorikan dalam kelompok orangorang Lewi (lih. 1 Taw. 9:16). Serta, daftar orang-orang yang kembali dari pembuangan pada masa Zerubabel (lih. Ezr. 22). Pencarian sumber Alkitab mengenai Desa Gilgal tidak dapat ditemukan, kemungkinan terletak pada bagian utara Yerusalem. ${ }^{32}$ Namun, menurut C. F Keil, Desa Bet-Gilgal sebagaimana sekarang adalah kota Jijilia, masih juga disebut Gilgal, terletak di bagian barat jalan dari Yerusalem ke Nablous

\footnotetext{
${ }^{32}$ F.C. Cook, Barnes Notes The Bible Commentary Exodus to Ruth (Michigan: Baker Book House, 1879), 481.

${ }^{33}$ C. F. Keil dan F. Delittzsch, Biblical

Commentary on Old Testament (Grand Rapids: WM. B. Eermands Publishing company, 1950), 275.
}

(Sikhem), sekitar 17 mil dari kota dahulunya (Bet-Gilgal)." "33

Desa Geba dicatat pada konteks sebelumnya dalam Nehemia 11:31. Sebagian orang-orang Lewi dari Yehuda tinggal dengan orang Benyamin di daerah tersebut (Neh. 11:36). Desa Asmawet ditemukan pada daftar orang-orang yang kembali dari pembuangan pada masa Zerubabel (Ezr. 2:22). Orang-orang Lewi mempersiapkan pentahbisan tembok Yerusalem dengan membangun desa-desa bagi mereka diantara Yerusalem dan desanya masing-masing. ${ }^{34}$ Konteks sebelum Nehemia 12:27-28, cukup menjelaskan latar belakang tempat para Lewi yang telah kembali pulang di Yerusalem (Ezr. 2 dan Neh. 11).Pentahiran diri 12:30 Pentahiran diri merupakan bagian akhir dalam persiapan acara pentahbisan tembok Yerusalem. Pentahiran diri ini diikuti oleh para imam, orang Lewi, umat, pintu-puntu gerbang dan tembok (Neh. 12:30). Dari sisi kronologisnya, para imam dan orang Lewi mentahirkan dirinya, kemudian mentahirkan para umat, pintu-pintu gerbang dan tembok.

Kata pentahiran diambil dari bahasa Ibrani

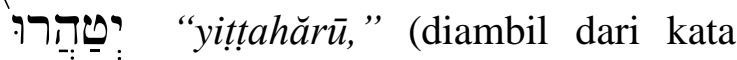
dasar טָּרָ "taher”). Kata tersebut diartikan sebagai pembersihan, penyucian dan pemurnian. ${ }^{35}$ Menurut konteks ayat 31-42, acara pentahbisan tembok Yerusalem diikuti oleh orang-orang yang sungguhsungguh mempersiapkan diri untuk memuji Allah. Apabila memperhatikan ayat 31-42, acara pentahbisan tembok Yerusalem diikuti dengan orang-orang yang telah siap untuk memuji Allah. ${ }^{36}$ Kata טַּה "yitțhărū," dalam sudut pandang Imamat, menjelaskan hal yang serupa dalam

\footnotetext{
${ }^{34}$ Laney, Ezra-Nehemia, 114.

${ }^{35}$ Willem A. VanGemeren, new international Dictionary of Old Testament Theology \& Exegesis volume 4 (Carlisle: paternoster press, 1996), 477.

${ }^{36}$ Keil dan F. Delittzsch, Biblical Commentary on Old Testament, 275
} 
Nehemia 12:30. Penyucian diri melibatkan semua orang dalam pentahbisan tembok Yerusalem. ${ }^{37}$ Dalam konteks yang lebih dekat, kitab 2 Tawarikh 29:31 juga memiliki kesamaan dengan Nehemia 12:30. Kesamaan ini dapat diperhatikan dalam korban persembahan dan pentahbisan. ${ }^{38}$

Di dalam kitab 2 Tawarikh 29:31, sebelum bangsa Israel melakukan korban sembelihan dan korban persembahan, raja Hizkia menjelaskan bahwa bangsa Israel telah mentahbiskan dirinya kepada Tuhan. Pada ayat tersebut menjelaskan, pentahiran diri sebagai suatu persiapan bagi bangsa Israel untuk melakukan korban sembelihan dan korban bakaran.

Orang Lewi, Bangsa Israel, pintupintu gerbang dan tembok-tembok ditahirkan sebagai bukti kesungguhan hati untuk mengiktui acara pentahbisan (Neh. 12:31-42). ${ }^{39}$ Pentahiran ini menjadikan orang-orang Israel nyaman ketika mempersiapkan diri untuk mengikuti pentahbisan tembok Yerusalem. ${ }^{40}$

\section{Acara pentahbisan tembok Yerusalem (12: 31-42)}

Acara pentahbisan tembok Yerusalem di dalam Nehemia 12:31-42 merupakan lanjutan dari prosesi mengelilingi tembok Yerusalem. Prosesi pentahbisan tembok diikutsertakan dengan puji-pujian, intstrumental musik dan pengucapan syukur sebagai bentuk sukacita umat (Neh. 12:31, 34-35, 40). Oleh sebab itu, Penulis akan menjelaskan tujuan dari prosesi pentahbisan tembok Yerusalem.

\footnotetext{
${ }^{37}$ Penyucian orang-orang Lewi dalam pekerjaannya di Tabernakel (Bilangan 8:6, 7, 15, 21). Van Gemeren, New International Dictionary of Old Testament Theology \& Exegesis, 344.

${ }^{38}$ Keil dan F. Delittzsch, Biblical Commentary on Old Testament, 275.

${ }^{39}$ Ibid.

${ }^{40}$ Matthew Henry's Commentary on the whole Bible Vol. II-Joshua to esther (Old Tappan:

Fleming H. Revell Company, 1950), 1112.
}

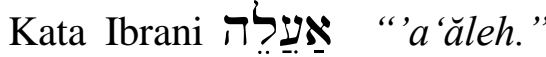

Diterjemahkan dalam bahasa Indonesia “ aku mempersilahkan pergi, naik dan mendaki." ${ }^{41}$ Nehemia menunjukkan pekerjaannya dalam peristiwa penahbisan tembok Yerusalem (Neh. 12:31). Nehemia hanya menjadi tokoh penggerak dalam prosesi pentahbisan ini dan turut mengambil bagian dalam prosesi pentahbisan pada kelompok kedua (Neh. 12: 38-42).

Dalam teks Ibrani Nehemia 12:31, dapat ditemukan secara jelas bagaimana pengaturan upacara pentahbisan ini dapat terlaksana. Kata Ibrani תִהְלָת "tahalekot"diartikan sebagai bentuk dari prosesi (kesungguhan dalam mengikuti prosesi), termasuk di dalamnya kata ini mengandung kepada arti korban syukur. ${ }^{42}$ Prosesi ini menujukan kesungguhan hati umat dalam mengakui imannya pada upacara pentahbisan tembok Yerusalem.

Pada ayat 31, penulis memperhatikan frase dalam bahasa Ibrani

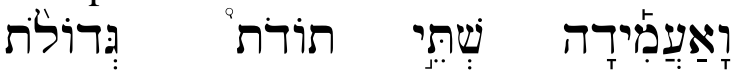
"wā'a'ămîdāh šatê tōowdōt gadōwlōt Dalam bahasa Indonesia diterjemahkan "Aku mendirikan 2 (dua) nyanyian syukur besar." Tampaknya, Nehemia telah mempersiapkan 2 (dua) kelompok paduan suara dan dibawa dalam prosesi pentahbisan tembokYerusalem. Kelompok nyanyian syukur ini memiliki tujuan untuk mengelilingi kota sambil memberikan ucapan syukur terbuka kepada Allah. ${ }^{43}$

Nehemia menetapkan 2 (dua) kelompok paduan suara yang akan berkeliling sepanjang tembokYerusalem. Kelompok pertama, beberapa imam dan orang Lewi pergi pada jalur kanan melalui

\footnotetext{
${ }^{41}$ Kata kerja piel waw consecutif Imperfek 1 umum tunggal. Carl Reed, diktat kuliah, Bahasa Ibrani Jilid 1, 2009.

${ }^{42}$ Keil dan F. Delitzsch, Biblical Commentary on Old Testament, 275.

${ }^{43}$ Pfeifer dan Everett F. Harrison, peny., John C. Whitcomb, jr, The Wycliffe Bible Commentary Volume 1 .
} 
pintu gerbang sampah (Neh. 12:31-37), sebagai pemimpin dari kelompok pertama yaitu Ezra (Neh. 12:36). Kelompok kedua, diikutsertakan Nehemia dengan kelompok paduan suara kedua (Neh 12:38).

Perjalanan paduan suara pertama 12:31-37

Penulis memperhatikan urutan dari prosesi kelompok paduan suara pertama dalam pentahbisan tembok Yerusalem. Dalam teks yang dijelaskan pasal 12: 31-37, Ezra yang berjalan pada bagian pertama mendahului bagian yang lainnya (Neh. 12:36). Barisan kedua terdapat kelompok nyanyian syukur yang diarahkan oleh Nehemia ke arah jurusan pintu gerbang sampah (Neh. 12:31). Barisan ketiga adalah Hosaya dan sebagian pemimpin orang Yehuda (Neh. 12:32-34). Barisan keempat adalah para imam yang memgang nafiri (Neh. 12:35). Sedangkan barisan kelima adalah pemain musik yang menyanyikan puji-pujian Daud (Neh. 12:36).

Paduan suara pertama ini tidak diketahui awal perjalanannya di dalam Alkitab. Namun, menurut Derek Kidner, "paduan suara pertama dimulai dari pintu lembah (sepertinya) yang terletak pada bagian barat tembok Yerusalem. Kelompok pertama pergi dengan berlawanan arah jarum jam menuju bagian selatan hingga kepada timur tembok." 44 Kelompok paduan suara pertama melalui pintu gerbang sampah (Neh. 12:31c). Lalu, paduan suara pertama pergi ke daearah pintu gerbang mata air, naik tangga-tangga kota Daud, istana Daud sampai pintu gerbang air yang terletak pada bagian timur tembok Yerusalem (Neh. 12: 37).

\footnotetext{
${ }^{44}$ Kidner, Ezra and Nehemiah An Introduciton and Commentary, 136-137.

${ }^{45}$ Keil dan F. Delitzsch, Biblical Commentary on Old Testament, 277.

${ }^{46}$ Carl A. Reed, Diktat Kuliah, Eksposisi kitab

Mazmur, Program S-2, April 2014.

${ }^{47}$ Nissim Amzallag and Mikhal Avriel, "Psalm 122 as the Song Performed at the Ceremony of
}

Perjalanan paduan suara pertama dijelaskan kembali ketika bangsa Israel mulai membangun kembali tembok Yerusalem (Band. Neh. 12:31c, 37 dengan Neh.2:13 dan 3:13-26). Paduan suara pertama memberikan alat musik Daud yang diiringi para abdi Allah (Neh. 12:36, band. Neh. 12:46), dengan memperhatikan frase

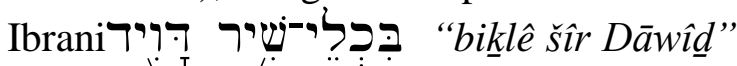
diterjemahkan sebagai "alat pujian Daud." Kelompok Pertama menyanyikan mazmur pujian dan mengagungkan Allah dengan alat musik instrument. ${ }^{45}$ Dalam konteks jauh, pujian syukur dijelaskan sebagai jenis "Mazmur Todah."46 Mazmur 122 menunjukan ungkapan syukur dalam ibadah Israel yang memiliki hubungan dengan Pentahbisan tembok Yerusalem dalam Nehemia 12:27-43. ${ }^{47}$ Khusus pada Mazmur 147:1-6, Pemazmur menjelaskan pemulihan pada masa pasca pembuangan. ${ }^{48}$

Dengan pernyataan di atas, kelompok pertama memberikan puji-pujian kepada Allah sebagai rasa terima kasih atas perbaikan tembok Yerusalem (Neh. 3:1326). Bangsa Israel diingatkan kembali dalam tuntunan Allah. Sehingga, bangsa Israel akan mengingat apa yang telah dikerjakan oleh Allah dengan sukacita dan korban syukur.

Pada ayat 37, kelompok pertama menaiki tangga-tangga kota dan istana Daud dalam prosesi pentahbisan. Pada pasal 12, penulis memperhatikan kata Daud disebut 6 (enam) kali. 3 (tiga) ayat menekankan kepada peran orang Lewi yang telah ditetapkannya (Neh. 12:24, 45, 46) dan 2 (dua) ayat menjelaskan prosesi melewati kota dan istana Daud (Neh. 12:36, 37). Dalam konteks dekat Nehemia 12:4546, Daud memerintah para orang-orang

\footnotetext{
Dedication of the City Wall of Jerusalem (Nehemiah 12, 27-43)," Scandinavian Journal of the Old Testament 30, no. 1 (2016): 44-64, https://doi.org/10.1080/09018328.2016.1122289. ${ }^{48}$ Pfeifer dan Everett F. Harrison, peny., Kyle M. Yates, The Wycliffe Bible Commentary volume 2, 274.
} 
Lewi di dalam tugas pelayanan dan pentahiran di dalam tugas peribadatan. Hal tersebut, diingatkan kembali ketika Daud memberi pekerjaan dalam ibadah di rumah Tuhan (lih. 1 Taw. 23:24).

Perjalanan paduan suara kedua 12:38-39

Perjalanan paduan suara kedua diikuti oleh Nehemia untuk mengelilingi tembok Yerusalem yang berbeda jalur dengan paduan suara pertama. Frase Ibrani

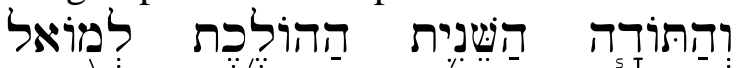
"wahattōwdāh haššentît hahōwleket ləmōwl" Dalam bahasa Indonesia diterjemahkan, "lalu nyanyian syukur kedua sedang berjalan berlawanan..." Hal tersebut menunjukan konteks pada ayat 31, dimana kelompok pertama pergi ke arah kanan. Kelompok kedua pergi ke arah kiri dan utara tembok Yerusalem. ${ }^{49}$ Perjalanan kelompok korban syukur pertama dan kedua telah meliputi seluruh tembok Yerusalem.

Pada ayat 38, perjalanan paduan suara kedua diawali dari menara perapian sampai tembok lebar. Tempat perjalanan paduan suara disebut kembali ketika para pekerja memperbaiki tembok Yerusalem (Neh. 3:111, 28-32). Tembok Yerusalem menjadi peringatan bagi bangsa Israel atas kesetiaan dan perlindungan Allah dari musuh-musuh yang mencoba untuk menghalangi pembangunan ini. ${ }^{50}$

Pentahbisan tembok Yerusalem oleh paduan suara pertama dan kedua telah memberikan suatu catatan kembali di dalam Nehemia 3. Tembok Yerusalem telah menjadi bukti bagi bangsa Israel di mana Allah telah bekerja selama pembangunan tembok Yerusalem (Neh. 3-6). Nehemia menjadi penggerak dalam pembangunan tembok Yerusalem, namun Allah yang menjadi pusat penyembahan dalam acara pentahbisan tembok Yerusalem.

\footnotetext{
${ }^{49}$ Seume, Nehemia: God's Builder, 104.

${ }^{50}$ Donald K. Campbell, Nehemia: Man in Charge

(England: Scripture Press Publications, 1949), 105.
}

Bangsa Israel mempunyai kenangan pada masa pembuangan Persia. Hal tersebut menjadi titik tolak bagi bangsa Israel datang kembali kepada Allah. Perbudakan oleh dosa (Neh. 9:28-35) dan perkawinan campuran bukan menjadi alasan untuk umat Israel merasa bersalah. Jawaban dari hasil pengucapan syukur terlihat kepada respon umat yang kembali kepada ibadah Israel.Akhir perjalanan di bait suci $12: 40-42$

Nehemia 12:40-42 menjelaskan bahwa kedua paduan suara telah berdiri di bait Allah. Nehemia bersama-sama dengan beberapa penguasa (gubernur) dan para imam (ay. 41). Serta, para penyanyi memperdengarkan puji-pujian yang dipimpin oleh Yizrahya. Akhir perjalanan di bait suci adalah mengadakan persembahan korban (ay. 43).

Dengan memperhatikan analisis pentahbisan tembok Yerusalem di atas, maka pada bagian ini, penulis

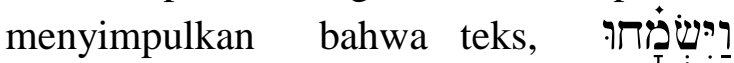

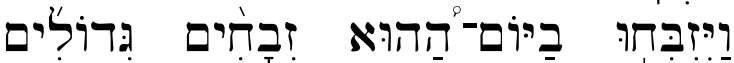

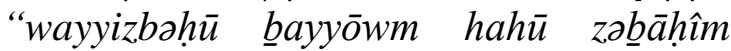
gadōwlim wayyiśmāhūu," yang diterjemahkan dalam bahasa Indonesia "di dalam hari itu mereka mengorbankan korban besar dan sukacita," pada ayat 43 ditemukan ada 2 (dua) pokok dari pentahbisan tembok Yerusalem.

$\begin{array}{ccc} & \text { Pertama, Pentahbisan } & \text { tembok } \\ \text { Yerusalem } & \text { dirayakan } & \text { dengan }\end{array}$ mempersembahkan korban bakaran yang besar (Neh. 12:43a). Dalam bahasa Ibrani

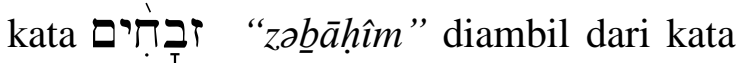
dasar “zabakh”). Kata tersebut diartikan sebagai korban keselamatan, korban persembahan (sesuatu yang berhubungan dengan kebiasaan dalam hukum taurat), menyembelih. ${ }^{51}$ Menurut William Dyrness," korban keselamatan

\footnotetext{
${ }^{51}$ Peraturan Hukum Taurat dan sebagian besar dari peristiwa koban persembahan yang dilakukan pada masa sejarah Israel, berkaitan dengan upacara yang sangat mendasar dalam memakan daging dan darah
} 
(zebah atau selamim) imamat 7:11-18 adalah,Suatu upacara persembahan untuk menyatakan syukur kepada Allah, atau mungkin sebagai pembayaran suatu nazar. Korban ini juga dapat disantap sebagai santapan istimewa pada hari persembahan itu." 52

Korban keselamatan telah ada pada konteks hukum Taurat (Im. 7). Korban keselamatan diartikan sebagai korban syukur (dalam bahasa Ibrani תiֹרדה "toda"). ${ }^{53}$ Hasil dari Korban keselamatan dirayakan dalam seruan sukacita (pujipujian) yang tampak pada keseluruhan orang-orang Israel. Hal tersebut mendukung pokok di dalam frase berikutnya bahwa bangsa Israel merayakan pentahbisan tembok Yerusalem dalam keadaan bersukacita (Neh. 12:43).Kedua, pentahbisan tembok Yerusalem dirayakan dengan sukacita. Dalam teks Ibrani, kata

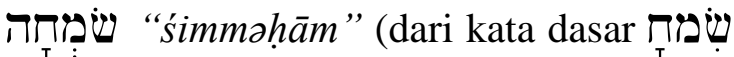
"shimakh") yang diartikan sebagai sukacita terletak di dalam Nehemia 12:27 dan $43 .{ }^{54}$ Penjelasan mengenai sukacita pada kedua ayat tersebut, sama-sama menjelaskan situasi pada saat bangsa Israel mempersembahkan korban keselamatan.

Penulis memperhatikan frase

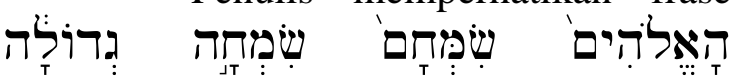
"hā'élōhîm śimmahām śimhāh ḡadōwlāh."

korban binatang yang telah disucikan oleh Allah pada hari raya besar Israel(Kej. 46:1, Kel. 10:25 dan 2 Taw 7: 4). Brown, The New Hebrew and English Lexicon With An Appendix Containing The Biblical Aramic, 257.

${ }^{52}$ William Dyrness, Tema-tema dalam Teologi Perjanjian lama (Malang: Gandum Mas, 2009), 135.

${ }^{53}$ Kata תiרוֹר "todot” adalah salah satu kata yang berhubungan dengan konsep pujian. Panggilan untuk memuji diungkapkan 24 kali dengan istilah Hallelu-Yah. Kata ini diartikan sebagai panggilan untuk para penyembah TUHAN untuk mempersembahkan seruan sukacita spontan karena telah menikmati pertolongan Allah. Reed, Diktat
Frase tersebut diterjemahkan dalam bahasa Indonesia "Allah yang telah membuat mereka sukacita besar." K5 Kata "פ "ki" yang diartikan sebagai "sebab, karena." Kata ini diartikan sebagai "sebab dan pengaruh" dimana Allah telah memberikan sukacita besar pada bangsa Israel. Keberhasilan pentahbisan tembok Yerusalem dapat diperhatikan ketika peran Allah memberkati keseluruhan pentahbisan tersebut. Pada konteks jauh, Ezra 6:22 menjelaskan ungkapan sukacita besar dalam pentahbisan rumah Allah dan perayaan hari raya paskah. ${ }^{56}$ Hasil dari pentahbisan Yerusalem dapat diperhatikan dalam Nehemia 12:43c, "perempuan dan anakanak bersukacita dalam kesukaan besar, sehingga kesukaan Yerusalem terdengar sampai jauh." Seluruh bangsa Israel merayakan pentahbisan tembok Yerusalem. Tujuan dari pentahbisan tembok Yerusalem adalah menunjukan sukacita besar, karena Allah telah memberikan keberhasilan kepada bangsa Israel di dalam pembangunan tembokYerusalem. ${ }^{57}$

\section{Hasil Temuan}

Berdasarkan kajian dalam tulisan ini, maka penulis akan menyajikan beberapa temuan terhadap Pentahbisan tembok Yerusalem di

Kuliah, Eksposisi kitab Mazmur, Program S-2, April 2014.

${ }^{54}$ Carl A. Reed, Diktat Kuliah, Kamus Sementara Bahasa Ibrani-Bahasa Indonesia Edisi kedua, sem. VI, 2010.

55 Bible Works “" $\sim$ X'M.f” 1 “ kata kerja menggunakan akhiran ganti 3 (tiga) maskulin jamak yang diartikan "bersukacita" dalam Bible Works $N T(B N T)$, ver. 7.0, Software:Bible Works For Windows. CD-ROM.

${ }^{56}$ Pfeifer dan Everett F. Harrison, peny., John C. Whitcomb, The Wycliffe Bible Commentary volume 2,1187 .

${ }^{57}$ Keil dan F. Delitzsch, Biblical Commentary on Old Testament, 277. 
dalam Nehemia 12:27-43 serta makna teologis bagi kehidupan bangsa Israel pasca pembuangan di Babel. Ada 3 (tiga) hal yang akan diperhatikan oleh penulis di dalam makna teologis pentahbisan tembok Yerusalem (Neh:12-27-43).

Pertama, penulis akan membahas peran Allah di dalam acara pentahbisan tembok Yerusalem. Allah memberi sukacita di dalam acara pentahbisan tembok Yerusalem. Teks Nehemia 12:27-43 mencatat pada bagian seluruh acara pentahbisan tembok Yerusalem diselanggarakan dengan penuh sukacita (ay. 27, 43). Dari sudut pandang yang lain, Allah sangat berperan dalam keberhasilan pembangunan kembali tembok Yerusalem. Allah memakai Nehemia sebagai penggerak dalam pembangunan ini. Allah telah menuntun dan melindungi bangsa Israel pada saat membangun tembok Yerusalem. Hal tersebut Nampak ketika bangsa Israel mengelilingi tembok Yerusalem untuk mengingatkan kembali akan pekerjaan Allah dalam pembangunan kembali tembok Yerusalem (Neh. 12:2742). Oleh sebab itu, peran Allah dalam pentahbisan tembok Yerusalem dapat diperhatikan ketika Allah memberi sukacita dan menuntun bangsa Israel dalam pentahbisan tembok Yerusalem.

Kedua, penulis akan membahas kepentingan korban syukur bagi Israel. Korban syukur (korban keselamatan) yang dilaksanakan dalam pentahbisan tembok Yerusalem merupakan wujud dari persembahan pujian dalam sistem korban Lewi. Kepentingan umat Israel dalam korban syukur ini sangat penting untuk dibahas dalam mencari nilai-nilai teologis.

Ketiga, penulis akan membahas kepentingan puji-pujian bagi Israel. Pujipujian sangat mengambil peran dalam acara pentahbisan tembok Yerusalem. Teks Nehemia 12:31-42 menjelaskan bagaimana

\footnotetext{
${ }^{58}$ Paulus Daun, Teologi Proper (Doktrin Tentang Allah) (Manado: Yayasan “Daun Family”, 2008), 99.
}

bangsa Israel melakukan acara pentahbisan tembok Yerusalem dengan melakukan pujipujian kepada Allah. Pada konteks sebelumnya, teks Nehemia 12: 28-29 menunjukkan persiapan orang Lewi untuk acara pentahbisan tembok Yerusalem dengan alat-alat musik seperti ceracap, gambus dan kecapi.

Ketiga aspek tersebut di atas akan menjelaskan kepada kehidupan umat Israel pada masa pasca pembuangan. Tentunya hasil dari upacara penahbisan tembok Yerusalem mengembalikan corak ibadah Israel yang sesungguhnya. Pengkhususan umat akan memberikan perubahan yang berbeda seperti kehidupan umat Israel pada masa pembuangan ataupun pra-pembuangan.

Konteks sesudah Nehemia 12:27-43 merupakan hasil dari penahbisan tersebut (Neh. 12:44:47). Selain melihat kembalinya para imam dan orang-orang Lewi, tindakan nyata bangsa Israel telah memberikan sumbangsih besar bagi para Imam dan tugas pelayanannya kepada Allah.Peran Allah bagi Israel

Peran Allah dapat diperhatikan dalam keseluruhan acara pentahbisan tembok Yerusalem. Bahkan lebih daripada itu, peran Allah dalam pentahbisan tembok Yerusalem menjelaskan keseluruhan kitab Nehemia, dimana Allah memberi sukacita dan menuntun dalam perbaikan kembali tembok Yerusalem (Neh. 12:28-43).

Allah tidak memisahkan diriNya bagi bangsa Israel pada masa pasca pembuangan. Namun, Allah menunjukan perbuatanNya yang konkrit sebagai wujud dari sifat kebaikanNya. ${ }^{58}$ Sifat kebenaran Allah secara tidak langsung dijelaskan pada teks Nehemia 12:27-43. Pentahbisan tembok Yerusalem tidak akan terlepas pada perbuatan Allah yang telah memberikan intervensi ${ }^{59}$ di dalam pentahbisan tembok Yerusalem.

\footnotetext{
${ }^{59}$ Campur tangan dalam suatu masalah. R. Suyoto Bakir dan Sigit Suryanto, Kamus Lengkap Bahasa
} 


\section{Allah memberi sukacita}

Bangsa Israel sangat bersukacita di sepanjang acara pentahbisan tembok Yerusalem. Di dalam perjanjian lama, sukacita bangsa Israel sangat berkaitan di dalam acara korban syukur (korban keselamatan) dan puji-pujian. Korban syukur dijadikan sebagai seruan sukacita spontan karena bangsa Israel telah menikmati anugerah Allah. ${ }^{60}$ Di dalam perjanjian lama, semua perayaan korban syukur Israel diadakan dengan keadaan bersukacita kepada Allah (band. Im. 7 ; 2 Raj. 20:13; 2 Taw. 7:10; Ezr. 3:13; 6:22; Neh. 12:27-43).

Penulis memperhatikan seluruh kronologis acara pentahbisan tembok Yerusalem. Pentahbisan tembok Yerusalem diadakan dengan penuh sukacita oleh seluruh umat Israel pada bagian persiapan, prosesi acara dan pemberian korban keselamatan. , korban syukur (korban keselamatan) tidak akan dipisahkan dalam rasa syukur bangsa Israel dengan ungkapan sukacita tersebut. Umat Israel melakukan korban syukur dan puji-pujian kepada Allah dengan menunjukan sukacita besarnya. ${ }^{61}$

Pokok di dalam pentahbisan tembok adalah sukacita. Sukacita yang diungkapkan oleh bangsa Israel adalah pernyataan terima kasih kepada Allah atas segala kesetiaan dan anugerahNya dalam pembangunan tembok Yerusalem. Pentahbisan tembok Yerusalem telah menunjukan karunia Allah kepada seluruh bangsa Israel.

Indonesia (Batam: Karisma Publishing Group, 2006), 229.

${ }^{60}$ Carl A. Reed, Diktat Kuliah, Eksposisi kitab Mazmur, Program S-2, April 2014.

${ }^{61}$ Peter J Gentry, "Nehemiah 12 : Restoring the City of God or How to Preach a List of Names,"

\section{Allah menuntun perbaikan tembok Yerusalem}

Keseluruhan kitab Nehemia menjelaskan peran Allah dalam menuntun perbaikan tembok Yerusalem. Allah menjaga bangsa Israel dari musuhmusuhnya (seperti: Sanbalat dan Tobia dalam Nehemia pasal 4), supaya pembangunan tembok Yerusalem tidak dapat dibangun kembali. Nehemia memiliki banyak tantangan di dalam pembangunan kembali tembok Yerusalem. Namun, teks Nehemia 3-6 menjelaskan bagaimana usaha-usaha pembangunan tembok Yerusalem dapat berjalan dengan baik. Peran Allah menyertai usaha-usaha perbaikan tembok Yerusalem, sehingga pentahbisan tembok Yerusalem dapat berjalan dengan baik.

Umat Israel bersyukur kepada Allah atas penyertaanNya dalam memperbaiki tembok Yerusalem. Allah telah menunjukan sifat kebenaranNya dalam pentahbisan tembok Yerusalem. Menurut Charles C. Ryrie, Sifat kebenaran berarti "sesuai dengan apa yang digambarkan" dan mencakup gagasan tentang kejujuran, kesetiaan, dan konsistensi. Mengatakan bahwa Allah benar adalah mengatakan, dalam pengertian yang paling luas, bahwa Ia konsisten dengan diriNya sendiri, bahwa Ia adalah semua sebagaimana seharusnya, bahwa Ia telah menyatakan diriNya sebagaimana sebenarnya, dan bahwa Ia dan penyertaanNya adalah sepenuhnya dapat dipercaya. ${ }^{62}$ Sifat kebenaran Allah dapat diwujudkan di dalam janji-janji (konsistensi) penyertaan Allah. Allah tidak

The Southern Baptist Journal of Theology 9, no. 3 (2005): 1-3, https://ixtheo.de/Record/1645739562.

${ }^{62}$ Charles C. Ryrie, Teologi Dasar 1 (Yogyakarta: ANDI Press, 1991), 58. 
dapat diingkari atau tidak digenapi di dalam perkataanNya. ${ }^{63}$ Namun, Allah tetap menunjukan kesetiaanNya di dalam janjiNya. Pentahbisan tembok Yerusalem tidak terlepas pada penyertaan Allah melalui kesetiaanNya. Sejak dari masa pembuangan sampai pada pasca pembuangan, Allah tidak pernah mengabaikan bangsa Israel. Nehemia dan seluruh umatNya pada masa pasca pembuangan telah mengalami janji tersebut ketika kedua kelompok paduan suara mengingat kembali kemurahan Allah. Menurut David M. Howard, "dalam kitab Nehemia, kasih karunia atau rahmat Allah kepada umatNya merupakan satu tema besar. Karunia Allah dapat dilihat sebagai "kemurahan tanganNya" atau "keprkasaan tangan-Nya." ${ }^{\circ 4}$ Alasan-alasan tersebut dapat diperhatikan ketika bangsa Israel dapat dipulangkan kembali di Yerusalem. Sifat kesetiaan Allah telah menunjukan janji, kemurahan dan kasih karuniaNya yang tidak pernah lepas bagi umat Israel. ${ }^{65}$

Penulis dapat memberikan kesimpulan mengenai peran Allah bagi Israel. Adapun 2 (dua) hal yang dijadikan kesimpulan pada bagian ini. Pertama, Allah memberi sukacita bagi Israel sebagai rasa syukur kepada Allah. Kedua, Allah menunjukkan sifat kebenaranNya dengan kesetiaan dan penggenapan JanjiNya bagi Israel. Pentahbisan tembok Yerusalem telah mempelajari sifat-sifat Allah yang telah berperan besar bagi bangsa Israel.

\section{Kepentingan bangsa Israel dalam korban syukur}

Pentahbisan tembok Yerusalem dirayakan dengan memberikan korban syukur kepada Allah. Korban syukur merupakan salah satu bagian penting di

\footnotetext{
63 Ibid.

${ }^{64}$ Howard Jr, Kitab-Kitab Sejarah dalam Perjanjian Lama, 386.

${ }^{65}$ Farel Yosua Sualang, "Studi Eksegesis Mengenai Kerajaan Mesias Menurut Yesaya 2:1-4,"
}

dalam pentahbisan tembok Yerusalem. Orang-orang Lewi telah dipanggil oleh Nehemia untuk mengadakan acara pentahbisan tembok Yerusalem. Korban binatang menjadi sarana dari tindakan persembahan korban syukur kepada Allah.

Bangsa Israel mengadakan korban syukur sebagai rasa ucapan terima kasih kepada Allah. ${ }^{66}$ Kepentingan tersebut sangat diperhatikan ketika bangsa Israel memberikan pengakuannya pada acara pentahbisan tembok Yerusalem. Korban syukur (korban keselamatan) memberikan keinginan umat Israel untuk memelihara hubungan baik kepada Allah. Bangsa Israel mengadakan korban syukur sebagai tindakan wajib untuk tetap menjaga hubungan baik kepada Allah. ${ }^{67}$

Peran dari Nehemia dan umat Israel dalam pembangunan dan penahbisan tembok Yerusalem, mengembalikan tujuan rohani untuk taat kepada Allah. Hal tersebut tampak dari pembangunan tembok Yerusalem (Neh. 2-6), pembaharuan rohani umat Israel oleh Ezra (Neh.8-10) dan puncaknya pada penahbisan tembok Yerusalem (Neh. 12:27-43). Pentahbisan tembok Yerusalem merupakan tingkatan pembaharuan untuk mengembalikan hubungan kepada Allah melalui pemberian korban syukur. Sehingga, pada Nehemia 12:44-47, umat Israel telah mencerminkan tindakannya untuk taat kepada Allah (seperti: korban syukur, perpuluhan dan persembahan kepada Harun).

Korban syukur telah memberikan suatu penerapan rasa terima kasih kepada Allah bagi kepentingan umat Israel pada masa pasca pembuangan. Kesimpulan dari praktek korban syukur adalah memberikan kesempatan kepada umat Israel untuk dapat kembali kepada Allah. Hal ini dapat

\footnotetext{
HUPERETES: Jurnal Teologi Dan Pendidikan

Kristen 1, no. 2 (June 29, 2020): 103-17, https://doi.org/10.46817/huperetes.v1i2.1.
${ }^{66}$ H. H. Rowley, Ibadat Israel Kuno (Jakarta: BPK Gunung Mulia, 2012), 100.

${ }^{67}$ Ibid.
} 
diperhatikan terhadap kembalinya peranan Imam dan kesadaran bangsa Israel untuk memberikan korban persembahan (Neh. 12:44-47). Baik sebagai bentuk bersyukur, tindakan pertobatan ataupun memberikan suatu persembahan kepada Allah.

\section{Kepentingan umat Israel dalam memuji Tuhan}

Di dalam perjanjian lama, unsurunsur pujian kepada Allah sangat berperan bagi kehidupan bangsa Israel. Kitab Keluaran 15:1-21, Musa digerakan oleh Roh Tuhan supaya dapat mengajak dan memimpin orang-orang Israel untuk memuji Tuhan. Musa dan Miryam adalah pemimpin-pemimpin pujian di dalam sejarah peribadatan Israel.

Sejak itu, para pemimpin pujian dipimpin oleh kaum Lewi, sehari-harinya hanya bertugas sebagai pelayan di bait Allah. Pada kitab 1 Tawarikh 6:31-47, Daud mengangkat ahli-ahli musik, seperti: Asaf, Heman dan Etan. Pada keturunan inilah kemudian membentuk suatu komunitas musik atau puji-pujian di dalam bait Allah. ${ }^{68}$ Terlebih khusus di dalam penahbisan Tembok Yerusalem (Neh. 12:27-43) Kembalinya umat Israel untuk memuji Tuhan mengembalikan unsur utama ibadah di bait suci. Konteks sesudah dari Nehemia 12:27-43 menunjukkan peranan imam yang mengembalikan fungsi awalnya dalam memuji Tuhan (Neh. 12:46). Hal tersebut terlihat jelas ketika Nehemia dan semua orang Israel memberikan sumbangan bagi para imam (Neh. 12:47). Bangsa Israel perlu untuk mengucap syukur atas pimpinan Allah di dalam keberhasilan pentahbisan tembok Yerusalem. Puji-pujian sebagai wujud dari ekspresi sukacita kepada Allah dalam pelaksanaan pentahbisan tembok Yerusalem.
${ }^{68}$ Mawene, Gereja yang bernyanyi (Yogyakarta: ANDI offset, 2004), 82.
Hubungan puji-pujian dan korban syukur (korban persembahan) menjadi bagian penting dalam konteks ini. Hal tersebut dapat diperhatikan ketika isi dari korban syukur telah menjelaskan puji-pujian sebagai sistem dari upacara korban syukur. Alasan ini dapat memperhatikan arti ibadah bagi umat Israel pada pasca pembuangan.

Pada arti yang sesungguhnya, Orang hadir di bait suci memiliki tujuan untuk memuji Tuhan karena pemberian dan campur tangan Allah bagi umat Israel. ${ }^{69}$ Bangsa Israel memberikan puji-pujian kepada Allah sebagai rasa terima kasih atas perbaikan tembok Yerusalem (Neh. 3:1326). Tidak heran apabila respon umat dalam puji-pujian akan menjadi bagian penting bagi Israel untuk bersyukur kepada Allah.

\section{KESIMPULAN}

Dengan demikian dapat disimpulkan bahwa, Upacara penahbisan tembok Yerusalem yang dilaksanakan oleh Nehemia memiliki pembaharuan besar bagi kehidupan ibadat Israel. Pada masa pasca pembuangan tindakan pertobatan dan pengakuan dosa menjadi awal bagi bangsa Israel untuk kembali kepada Allah (Neh. 810). Nehemia menjadi sosok pemimpin yang mengembalikan pola ibadah Israel untuk bersekutu kepada Allah. Pembangunan tembok Yerusalem dijadikan sebagai dasar utama dimana bangsa Israel mengembalikan hubungan pribadi kepada Allah melalui ritus-ritus keagamaannya.

Pembaharuan ibadat Israel dapat diperhatikan di dalam 2 (dua) tema besar di dalam kitab Nehemia. Pertama, usaha Nehemia di dalam pembangunan tembok Yerusalem. Kedua, periode pemulihan: pembaharuan dan benih-benih Israel. Kedua tema tersebut telah dilaksanakan di dalam penahbisan tembok Yerusalem yang berisikan ritual-ritual agama Yahudi.

${ }^{69}$ Rowley, Ibadat Israel Kuno, 82. 
Kehadiran Nehemia memiliki peran kepada pembaharuan Israel pasca pembuangan Israel di Babel. Sekalipun upacara ini memperhatikan latar belakang sejarah budaya Israel kuno dan Pemerintahan Persia.

\section{DAFTAR PUSTAKA}

[1]. Amzallag, Nissim, and Mikhal Avriel. "Psalm 122 as the Song Performed at the Ceremony of Dedication of the City Wall of Jerusalem (Nehemiah 12, 27-43)." Scandinavian Journal of the Old Testament 30, no. 1 (2016): 44-64. https://doi.org/10.1080/09018328.2016.112 2289.

[2]. Bakir R. Suyoto, Sigit Suryanto, Kamus Lengkap Bahasa Indonesia. Batam: Karisma Publishing Group, 2006.

[3]. Baxter, Sidlow J. Menggali isi Alkitab 1 Kejadian-ester. Jakarta: Yayasan Komunikasi Bina Kasih, 2009.

[4]. Brown, Francis. The New Hebrew and English Lexicon With An Appendix Containing The Biblical Aramic. United states of America: Hendrickson Publisher, 1979.

[5]. Campbell, Donald K. Nehemia: Man in Charge. England: Scripture Press Publications, 1949.

[6]. Cook, F. C. Barnes Notes The Bible Commentary Exodus to Ruth. Michigan: Baker Book House, 1879.

[7]. Daun, Paulus. Teologi Proper (Doktrin Tentang Allah). Manado: Yayasan "Daun Family", 2008.

[8]. Dyrness, William. Tema-tema dalam Teologi Perjanjian lama. Malang: Gandum Mas, 2009.

[9]. Finkelstein, Israel. "Jerusalem in the Persian (and Early Hellenistic) Period and the Wall of Nehemiah." Journal for the Study of the Old Testament 32, no. 4 (2008):
501-20.

https://doi.org/10.1177/0309089208093928

[10]. Gentry, Peter J. "Nehemiah 12: Restoring the City of God or How to Preach a List of Names." The Southern Baptist Journal of Theology 9, no. 3 (2005): 1-3. https://ixtheo.de/Record/1645739562.

[11]. Harrington, Hannah. "The Use of Leviticus in Ezra-Nehemiah." Journal of Hebrew Scriptures 13 (2013): 1-19. https://doi.org/10.5508/jhs.2013.v13.a3.

[12]. Hill, Andrew E, John, H. Walton. Survey Perjanjian Lama. Malang: Gandum Mas, 2008.

[13]. Howard, David M. Kitab-kitab sejarah. Malang: Gandum Mas, 2009.

[14]. Keil, C. F, F. Delittzsch, Biblical Commentary on Old Testament. Grand Rapids: WM. B. Eermands Publishing company, 1950.

[15]. Kidner, Derek. Ezra and Nehemiah An Introduciton and Commentary. Illinois: Inter-Varsity Press, 1979.

[16]. Klein, William W, Craig Blomberg, dan Robert L. Hubbard. Introduction to Biblical Interpretation 2. Malang: Literatur SAAT, 2013.

[17]. Laney, J. Carl. Ezra-Nehemia. Chichago: Moody Press, 1982.

[18]. Matthew Henry's Commentary on the whole Bible Vol. II-Joshua to esther. Old Tappan: Fleming H. Revell Company, 1950.

[19]. Mawene, Gereja yang bernyanyi. Yogyakarta: ANDI offset, 2004.

[20]. Osborne, Grant R. Spiral Hermeneutika: Pengantar Komprehensif bagi Penafsiran Alkitab. Surabaya: Penerbit Momentum, 2012. 
[21]. Pfeifer, Charles F, Everett F. Harrison, peny., John C. Whitcomb, jr. The Wycliffe Bible Commentary (Malang: penerbit Gandum Mas, 2004.

[22]. Pratt, Jr, Richard L. Ia Berikan KisahNya: Panduan bagi Siswa Alkitab untuk Menafsirkan Narasi Perjanjian Lama. Surabaya: Penerbit Momentum, 2005.

[23]. Rowley, H. H. Ibadat Israel Kuno. Jakarta: BPK Gunung Mulia, 2012.

[24]. Ryrie, Charles C. Teologi Dasar 1 (Yogyakarta: ANDI Press, 1991), 58.

[25]. Saparman, Belajar Alkitab. Yogyakarta: STII Press, 2007.

[26]. Seume, Richard H. Nehemiah: God's Builders. Chicago: Moody Press, 1978.

[27]. Spellman, Ched. 'Nehemiah's New Shadow: Reading and Rereading the EzraNehemiah Narrative." Southeastern Theological Review 9, no. 1 (2018): 3. https://digitalcommons.cedarville.edu/bibli cal_and_ministry_studies_publications/437 /.

[28]. Sproul, R. C. Essential Truths of The Christian Faith. Illinois: Tyndale House Publisher, 1997.

[29]. Sualang, Farel Yosua. "Prinsip-Prinsip Hermeneutika Genre Hikmat Dalam Kitab Amsal: Suatu Pedoman Eksegesis." Jurnal PISTIS 1, no. Old Testament, Genre of Wisdom, Hermeneutics (2019): 93-112. https://doi.org/10.31227/osf.io/xmk6h.

[30]. . "Studi Eksegesis Mengenai Kerajaan Mesias Menurut Yesaya 2:1-4." HUPERETES: Jurnal Teologi Dan Pendidikan Kristen 1, no. 2 (June 29, 2020): 103-17. https://doi.org/10.46817/huperetes.v1i2.1.

[31]. The Interpreter's Dictionary of the Bible. New York: Abingdon Press, 1962.
[32]. Unger, Merril F. Unger's Bible Handbook. Chicago: Moody Press, 1967.

[33]. VanGemeren, Willem A. New international Dictionary of Old Testament Theology \& Exegesis volume 4. Carlisle: paternoster press, 1996.

\section{Diktat}

[34]. Reed, Carl A. Diktat Kuliah, Kamus Sementara Bahasa Ibrani-Bahasa Indonesia Edisi kedua, sem. VI, 2010. 